\title{
Do occupants change behaviour when their home is renovated?
}

\author{
Rune Korsholm Andersen, Jens Kristian Kruse Petersen, Ane Midtstraum \\ Technical University of Denmark, Department of Civil Engineering, Lyngby, Denmark
}

\begin{abstract}
In recent years, it has become apparent that households in energy inefficient buildings use less energy than the theoretical calculations predict, whereas households in the latest, most energy efficient buildings use more energy than provided in the theoretical calculations. Based on this, some have claimed that the energy efficiency of a building affects the occupants' behaviour in relation to heating so the occupants become less energy saving when the energy efficiency increases. It has been hypothesized that residents of energy efficient buildings have higher indoor temperatures and in general a more wasteful behaviour than occupants do in less efficient buildings.
\end{abstract}

This project tested that hypothesis by investigation of an extensive renovation of four apartment blocks in Denmark. The heat use was measured for eight years before the renovation and one year after the renovation. Before the renovation, indoor temperature, relative humidity and $\mathrm{CO}_{2}$ concentration was measured in the bedroom and living room at 5-minute intervals for 4 months in 17 apartments. After the renovation, indoor temperature and relative humidity was measured in the central corridor at 5-minute intervals in all apartments in one block (63 apartments).

No evidence in support of the hypothesis was found. In most of the apartments, the temperature measurements were similar before and after the renovation indicating that the occupants did not increase the heating set-point as a result of the renovation. The heat use was reduced by $64 \%$ after the renovation and the measured use after renovation was lower than the calculated estimate of energy use.

\section{Introduction}

The energy use and indoor environment of housing units is to a large extent controlled by the inhabitants' practices (Andersen et al., 2009). In identical townhouses, the heat use can vary by a factor of 20, so the highest use is 20 times higher than the lowest (Andersen, 2012) indicating that the residents' heating practices have a large impact on the heating use. As a consequence, a change in the residents' heating practices as a result of a building renovation has large potential to either enhance or inhibit the energy savings.

(Gram-Hanssen and Hansen, 2016) Compared the measured heat use of 135,000 single-family houses in
Denmark to their theoretical heating use in the energy labels. They found that well insulated houses (energy labels A, B and C) have a higher energy use than theoretically calculated. In contrast, poorly insulated houses (energy labels E, F and G) have a lower energy use than theoretically calculated. A similar study conducted on 536,000 households in The Netherlands found similar conclusions (Aydin et al., 2017).

The rebound effect can be described as the change in occupants' behaviour due to technological improvements and higher energy efficiency. An increase in energy efficiency will result in a decreased perceived cost of energy, which in turn will result in an increase in energy demand. Both Gram-Hansen and Hansen (2016) and Aydin et al. (2017) argued that the observed differences between the uses calculated in the energy certificate and the actual measured use are a sign of the rebound effect. I.e. the indoor temperature during the heating season is higher in well-insulated homes than in poorly insulated homes due to a higher energy efficiency and thereby a lower perceived cost of heating.

Gram-Hanssen and Hansen (2016) and Aydin et al. (2017) both state that there is a need for a better understanding of the rebound effect and the occupant behaviour in order to reduce energy use in buildings.

Measuring energy use before and after a renovation project gives an opportunity to study the reduction in actual energy use that occurs because of improvements made to the building. By measuring indoor climate parameters in the building before and after renovation, it might be possible to examine how the renovation has affected the indoor environment, and by that detect if there is a rebound effect.

In this paper, we have studied the indoor environmental aspects of the rebound effect by comparing measured indoor environment and energy use in an apartment building before and after an extensive energy renovation. 


\section{The building}

The measurements took place in an apartment building located in a suburb west of Copenhagen, Denmark. The building is part of a complex consisting of four similar buildings constructed in 1961.

Before the renovation, the four buildings consisted of 248 similar three-room apartments with a total floor area of $19,248 \mathrm{~m}^{2}$. The layout of some of the apartments was changed during the renovation resulting in 56 easy access apartments with access to an elevator and 188 apartments of varying sizes (two-roomed, three-roomed or fourroomed). The renovation of the first building began in December 2015 and was completed in November 2016.

\section{The renovation}

The facades of the buildings were moved out closer to the edge of the roof overhang, which created an additional apartment depth of 1-2 meters on each side of the building. Bays and balconies were built at one side of the building and apartments located at ground level had private gardens instead. The courtyards were also renovated to make them more lively and attractive to use. Passages to the courtyards were constructed in the middle of the buildings in order to guide more people through the courtyards. The roofing was renovated in the late 90's, and was still in good quality. It was therefore left untouched in the project.

Bathrooms and kitchens were completely renovated with new furniture and equipment. This included changing existing waste pipelines, changing the domestic water installations and establishing floor heating in the bathrooms. The heating system was changed from a onestring system to a two-string system. A balanced mechanical ventilation system with heat recovery was installed in the new facade and connected to the existing exhaust in the bathroom and the exhaust hood in the kitchen. The new air-handling units serviced one staircase each and was placed in the basement. District heating stations at each building block was renovated along with the pipelines connecting them. Lastly, all installations were insulated in order to decrease the heat loss.

To increase the tenants focus on energy use digital information monitors was installed in the hall of each apartment. The purpose of the information monitors was to display individual heat, water and electricity use for the tenants. In each apartment, the energy and water use was compared to the use in previous years, months and days. In addition, the monitors informed the tenants about the temperature and the relative humidity in their apartment.

\section{Measurements}

Indoor climate measurements were conducted in 17 apartments before the renovation from October 2016 to February 2017. The measurements were conducted using wireless instruments from Netatmo and included temperature, relative humidity and $\mathrm{CO}_{2}$ concentration measured with five-minute intervals in the bedroom and in the living room.

During the renovation of the apartments, wired temperature and relative humidity sensors were installed in the central corridor of each apartment and measured hourly values as average of samples taken every five minutes. The measurements in the renovated apartments were conducted from May 2016 to May 2017 (Table 1). Outdoor temperature was measured using a weather station located $12 \mathrm{~km}$ from the apartment building (DTU Climate Station).

Table 1: Overview of measurements before and after the renovation.

\begin{tabular}{|c|c|c|}
\hline & Before renovation & $\begin{array}{l}\text { After } \\
\text { renovation }\end{array}$ \\
\hline $\begin{array}{l}\text { Measurement } \\
\text { period }\end{array}$ & $\begin{array}{l}\text { October } 2015 \text { - } \\
\text { February } 2016\end{array}$ & $\begin{array}{c}\text { May } 2016 \text { - } \\
\text { May2017 }\end{array}$ \\
\hline $\begin{array}{l}\text { Number of } \\
\text { investigated } \\
\text { apartments }\end{array}$ & 17 apartments & 63 apartments \\
\hline $\begin{array}{l}\text { Measured } \\
\text { parameters }\end{array}$ & $\begin{array}{c}\text { Temperature, } \\
\text { Relative humidity } \\
\text { and } \mathrm{CO}_{2} \\
\text { concentration }\end{array}$ & $\begin{array}{c}\text { Temperature } \\
\text { and Relative } \\
\text { humidity }\end{array}$ \\
\hline
\end{tabular}

The total monthly heat use from before the renovation, from 2005 to 2014 (except for 2011), was made available by the housing association DAB (Dansk Almennyttig Boligselskab). The measured heat use included the heating of the domestic hot water and the space heating.

After the renovation, the use of space heating and domestic hot water (in liters) for the individual apartments was made available by the company Keep Focus. These measurements were conducted on an hourly basis. 


\section{Results}

All indoor temperature measurements from the living room before renovation were compared to temperature measurements from the central corridor after renovation in figure 1. The black curves represent the measurements from the living room before the renovation and the red curves represents the measurements from the corridor in the renovated apartments. The apartments had similar indoor temperatures before and after the renovation.

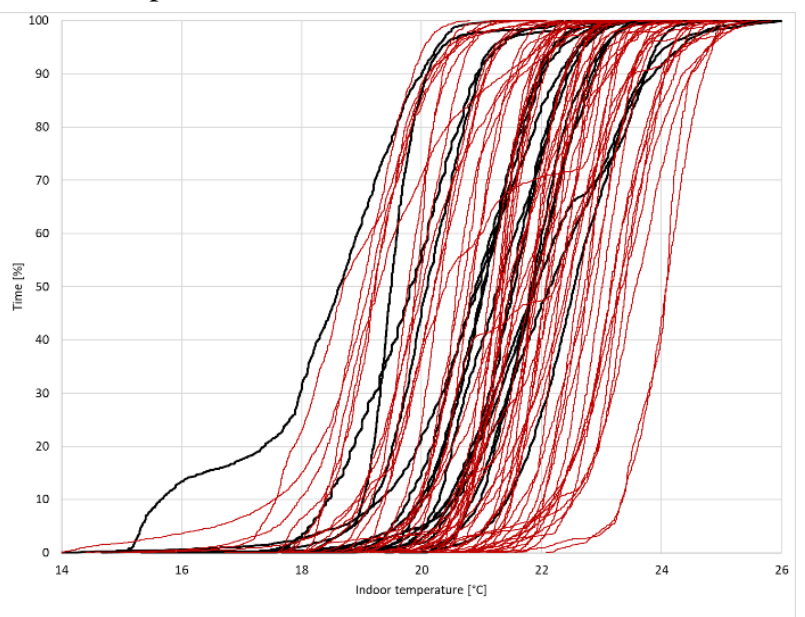

Figure 1: Cumulative temperature distribution before (black) and after the renovation (red).

The heat use is plotted in figure 2 as function of the outdoor temperature both before and after renovation. Each grey points represent a monthly heat use before the renovation from 2005-2014 (except for 2011). The red points represents the monthly heat use of the renovated apartment building from May 2016 until May 2017.
The data both before and after renovation closely followed a fitted line. The coefficient of determination were high $(>0.9)$ for both models, which indicates that more than $90 \%$ of the variation in monthly heat use was explained by the mean monthly outdoor temperature. The heat use before the renovation was more dependent on the outdoor temperature than after renovation.

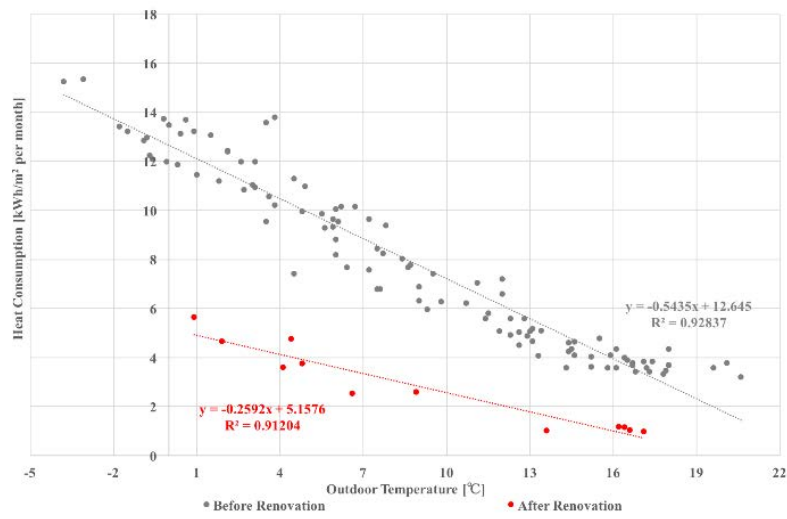

Figure 2: Monthly heat use (for space heating and domestic hot water) as a function of monthly mean outdoor temperature before (grey) and after (red) the renovation.

Figure 3 is a comparison of the calculated and measured heat use before and after the renovation. The actual heat use before renovation was almost half of the calculated heat use. In the renovated building, the difference between the calculated and measured use decreased.

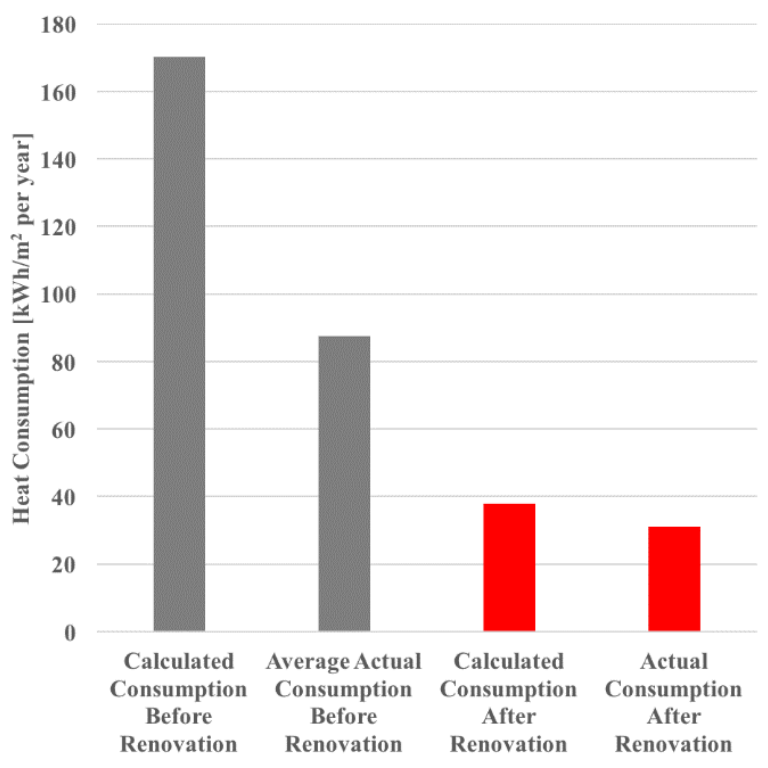

Figure 3: Comparison of the calculated and measured heat use before and after the renovation 


\section{Discussions}

The investigation of the indoor temperature showed an overall picture of no change before and after renovation, when comparing the 17 apartments before renovation with the 63 apartments after renovation (figure 1). The temperatures before the renovation were measured in the living room and were compared to temperature measurements from the corridor. The temperatures in the corridor and living room were most likely not identical and as such, large temperature differences between the two rooms would make the comparison invalid. To investigate potential large temperature differences between the corridor and living room, five renovated apartments were equipped with Netatmo measuring stations in the bedroom and living room. In these apartments, variations up to $2.6^{\circ} \mathrm{C}$ between the two rooms were observed. However, on average the difference was within the temperature sensors measurement error, indicating that there was no difference in the average temperature between the living rooms and the corridor.

Although the temperature measurements were compared for the same months, they were conducted in different years and therefore at different outdoor temperatures. The different outdoor temperatures could have influenced the residents' heating practices and thereby the indoor temperatures. However, a linear regression analysis revealed weak correlations between indoor and outdoor temperatures (correlation coefficients between 0.01 and 0.13 and coefficient of determination between 0.00 and 0.18 ), indicating that the indoor temperature was affected very little by the outdoor temperature during the heating season.

Aydin et al. (2017) found that that people living in rented homes experience larger rebound effects compared people living in owned homes. Additionally greater effects were found for lower income groups and for people with a higher heat use than the average. Since the measurements were conducted in rented apartments in social housing, a significant rebound effect was expected. However, the measured heat use was only slightly lower than the calculated heat use of the renovated building.

Gram Hansen et al. (2016) and Aydin et al. (2017) found that the predicted energy use was larger than the measured in homes with a poor energy certificate while the opposite was true in homes with a good energy certificate. The buildings in our investigation did not have an energy certificate before the renovation, but the low level of insulation prior to the renovation would have resulted in a poor energy certificate and the renovation would have improved the energy certificate by several steps. As a consequence, the observed differences in calculated and measured heat use confirms the findings of Gram Hansen et al. (2016) and Aydin et al. (2017). However, we found no change in indoor temperature indicating that the residents did not change their heating practices during the renovation. So the reduction in the difference between predicted and actual heating use after the renovation was not explained by changes in the occupants' heating practices as a result of the renovation. The large difference in predicted and actual heating use prior to the renovation may simply be a result of poor assessment of insulation levels and airtightness of the buildings prior to renovation.

\section{Conclusions}

The measured indoor temperatures were similar before and after the renovation indicating that the residents did not change their heating practices as a result of the renovation.

The heat use of the renovated building was less dependent on the outdoor temperature than before the renovation. This resulted in a measured $64 \%$ reduction in the heat use, which was a bit higher than the calculated reduction of $57 \%$. The difference in the measured and predicted heating use was much higher prior to the renovation, indicating signs of a rebound effect. However, the measured temperatures had similar distributions before and after the renovation, indicating that the occupants did not change their heating practices

\section{Acknowledgement}

This work was part of the project "Behaviour and use patterns in energy renovation of residential buildings" funded by ELFORSK with grant number 347-025.

\section{References}

Andersen, R. K. (2012) 'The Influence of Occupants' Behaviour on Energy Use Investigated in 290 Identical Dwellings and in 35 Apartments. Proceedings of Healthy Buildings 2012. Brisbane (Australia), 8-12 July 2012

Andersen, R., Toftum, J., Andersen, K.K. and Olesen, B.W. (2009). Survey of occupant behaviour and control of indoor environment in Danish dwellings. Energy and Buildings 41(1), 11-16. doi: 10.1016/j.enbuild.2008.07.004.

Aydin, E., Kok, N. and Brounen, D. (2017). Energy Effciency and Household Behavior: The Rebound Effect in the Residential Sector. RAND Journal of Economics 48(3), 749-782.

Gram-Hanssen, K. and Hansen, A. R. (2016). Forskellen Mellem Målt Og Beregnet Energiforbrug Til Opvarmning Af Parcelhuse. SBi 2016:09, ISBN 97887-563-1760-3

The Technical University of Denmark, Department of Civil Engineering. DTU Climate Station. Data. url: http://climatestationdata.byg.dtu.dk/GetData (visited on $06 / 20 / 2017)$. 